\title{
EFFECT OF PLANTING AND WATER TERMINATION DATES ON PRODUCTIVITY AND GRAIN QUALITY OF GIZA 179 RICE CULTIVAR
}

\author{
W. H. M. El-Kallawy \\ Rice Research Department, Field Crops Research Institute, Agricultural Research Center, \\ 33717 Sakha - Kafr El-Sheikh, Egypt, elkallawywael@yahoo.com
}

Received: Dec. 23, 2017

Accepted: Dec. 30,2017

\begin{abstract}
Planting dates and irrigation regimes are important aspects of successful rice production. In order to determine the effects of different planting and irrigation termination dates on productivity and some grain quality of Giza 179 rice cultivar, two sets of field experiments were initiated during 2016 and 2017 seasons at the Experimental Farm of Sakha Research Station, Kafr El-Sheikh, Egypt. Each experiment was laid out in a randomized complete block design (RCB), with four replications. In experiment (1), five planting dates were used (20 th April, $1^{\text {st }}$ May, $10^{\text {th }}$ May, $20^{\text {th }}$ May and $1^{\text {st }}$ June). However, in experiment (2), six dates for terminating irrigation were used (terminating irrigation after complete heading, 5, 10, 15, 20 and 25 days after complete heading). The results of experiment (1) showed that early in planting date $\left(20^{\text {th }}\right.$ April) took the longest duration to attain 50\% heading, however, there was a decreasing in plant height when planting was delayed beyond $10^{\text {th }}$ of May. Early $\left(20^{\text {th }}\right.$ April) and mid (1 $1^{\text {st }}$ and $10^{\text {th }}$ May) planting gave the highest values of number of panicles, panicle length, number of grains/panicle, panicle weight,1000 grain weight, grain and straw yields. However, late planting (20 ${ }^{\text {th }}$ May and $1^{\text {st }}$ June) significantly reduced all previous traits, but gave the highest unfilled grains percentage. Grain length and shape as well as milling and head rice percentage gradually increased with delaying of planting date. Also, planting dates had significant effects on amylose content, but there was insignificant effect on gel consistency and gelatinization temperature. The results of experiment (2) indicated that plant height, number of panicles $/ \mathrm{m}^{2}$ and panicle length were not significantly influenced by dates of irrigation terminates. The grain yield and its attributes (number of grains/panicle, panicle grain weight and 1000-grain weight) were significantly increased with delay withholding irrigation compared with earlier cut-off dates of irrigation, which recorded the highest unfilled grains percentage. There were no significant differences among the last three treatments, in first season and between the last two treatments, in second season for grain yield. Withholding irrigation immediately at complete heading recorded the minimum values of grain length, width, milling recovery (hulling, milling and head rice \%) and amylose content as compared with the other irrigation terminates .

Finally, it could be concluded that, , a planting date of $1^{\text {st }}$ and $10^{\text {th }}$ May might enable to achieve high grain yield for Giza 179 rice cultivar. However, delayed planting up to $20^{\text {th }}$ May achieve acceptable grain quality. Also, maximum grain yield and acceptable technological characters seem to be associated with delay in withholding of irrigation up to 20 days after complete heading.
\end{abstract}

Key words: Rice, planting date, irrigation termination, grain yield, grain quality.

\section{INTRODUCTION}

Rice (Oryza sativa L.) is one of the world's most important staple food crops, it is main diet of 3.5 billion people Liu et al., (2011). By the year 2025, it is necessary to produce about $70 \%$ more rice, than what is current production to meet the food needs of a growing world population Swaminathan (2007). Rice, following wheat, is the major staple for the large and growing population of the Egyptian. It occupies about 600 thousand hectares which represent about 
$22 \%$ of the cultivated area during summer season. Rice production must increase by about $20 \%$ to maintain current levels of consumption. Therefore, improvement in its yield while maintaining high quality is a long term goal in Egypt. Grain quality is not just depends on the variety of rice, but quality also depends on the crop production environment, harvesting, processing and milling systems. Times of planting and irrigation terminating dates are the important factors influencing grain yield of the crop. Although rice is consumed worldwide, therefore is no universal rice quality attribute Veronic et al., (2007). Nevertheless, rice appearance and cooked rice texture are the characters considered as main quality attributes by consumers Rousset et al.,(1999). Thus, measuring and understanding factors that influence appearance and texture properties are a great challenge for industries and breeders in meeting consumer preferences Haider et al., (2015).

Excessive heat during the pollination period and grain filling stage caused disorder in grain formation and grain weight which reduced the grain yield. So, correct planting time is crucial to achieve high yields and the best grain quality for rice. Therefore, optimum rice planting dates are regional and vary with location and genotypes Bashir et al., (2010). Selecting appropriate planting date is an important factor in the efficient management of crop adaptation to physiological processes and morphological. Planting rice after the optimum dates can result in higher disease and insect incidence, tropical storm-related lodging, and possible weather damage during heading and the grain filling period resulting in low yields Groth and Lee (2003). However, Slaton (2001) reported that planting earlier than the optimal date leads to lengthening of the time interval between cropping and grain maturity, longer pesticide and weeds control periods, more water consumption, biological yield enhancement and reduction in grain yield. On the contrary, most of the panicles become immature in delayed planting resulted in low grain yield.

Rice grain filling and ripening are affected by many environmental factors, including water, temperature, radiation, and soil nutritional conditions Yoshida (1981). So, scheduling last irrigation (terminating irrigation) at the correct stage of maturity may influence moisture content in grain at harvest and, then, affect on grain yield and quality. Whereas, cut-off irrigation on rice fields early may cause moisture stress in grains before they are physiologically mature, this may lead to lower harvest moisture contents associated with lower head rice yield. This practice causes a significant reduction in grain yield and increasing the unfilled, immature and broken, grains. However, delayed cut-off irrigation up to 3- and 4-weeks after complete heading significantly increased grain yield and most of its attributes, as well as grain quality Omar et al., (2012). ElRefaee (2007) reported that withholding of irrigation 21 days after heading is considered as the optimum timing of last irrigation to rice field to get high grain yield and quality.

Herein, the present study aimed to find out the optimum timing for planting and irrigation termination for higher grain yield and acceptable grain quality characteristics of Giza 179 rice cultivar.

\section{MATERIALS AND METHODS}

Two sets of field experiments were conducted, during 2016 and 2017 seasons, at the Experimental Farm of Rice Research and Training Center (RRTC), Sakha, Kafr ElSheikh, Egypt. The aim of these studies was to determine the effects of different planting dates (Experiment 1) and time for irrigation termination (Experiment 2) on productivity and grain quality of Giza 179 rice cultivar. Each experiment was laid out in a randomized complete block design (RCB), 
with four replications. Experiment (1) was conducted in different five successive planting dates by the difference of 10-days interval between each other viz.: (20 $0^{\text {th }}$ April, $1^{\text {st }}$ May, $10^{\text {th }}$ May, $20^{\text {th }}$ May and $1^{\text {st }}$ June). However, in experiment (2), six dates of irrigation terminating (terminating irrigation after complete heading $(\mathrm{ACH}), 0,5,10,15$, 20 and 25 days after complete heading $(\mathrm{DACH})$ were used. The meteorological data, according to Sakha Meteorological Station, of the experiment sites are showed in Table (1).

All experiments were preceded by flax (Linum usitatissimum) in both seasons. The soil was clay with $\mathrm{pH} 8.2$ and 8.0 and an organic matter content of 1.8 and $1.6 \%$. The total $\mathrm{N}$ was 520 and $500 \mathrm{ppm}$ in both seasons, respectively. The experiment (1) was sown according to the planting date treatment, however, the experiment (2) was sown on $1^{\text {st }}$ and $4^{\text {th }}$ of May in the two successive seasons. In both sets of field experiments, seeds of Giza 179 rice cultivar, at a rate of $96 \mathrm{~kg} / \mathrm{ha}$, were soaked in sufficient water for 24 hours and incubated for another 48 hours to enhance germination. Pre-germinated seeds were broadcasted, in the presence of water, after puddling the nursery. Three to four seedlings, 30 days old, were transplanted at $20 \times 20 \mathrm{~cm}$ distance among hills and rows, in plot size of $30 \mathrm{~m}^{2}(5 \times 6 \mathrm{~m})$ each. Phosphorus (35.5 kg $\mathrm{P}_{2} \mathrm{O}_{5} / \mathrm{ha}$ ), potassium (57 kg K2O/ha), nitrogen (165 kg N/ha, in the form of Urea $46 \% \mathrm{~N}$ ) and zinc (24 kg Zn $\mathrm{SO}_{4} / \mathrm{ha}$ ), as well as all other routine cultural practices were done, according to the recommendations to grow a successful rice crop. To avoid lateral movement and more water control, each main plot was separated by two meter wide ditches.

At harvest, plant height was randomly measured from ten hills for each unit plot, with the help of a meter scale from the base of the plant to the tip of the panicle. Number of panicles were recorded through counting the number from the randomly selected ten hills from each plot then, converted into numbers $/ \mathrm{m}^{2}$. Total number of grains/panicle, unfilled grains percentage and panicle length were counted from ten randomly selected panicles from each plot. The weight of 1000 grains was measured from taking random samples of each unit plot. The straw and grain yields were randomly measured from an area of $9 \mathrm{~m}^{2}(3 \times 3 \mathrm{~m})$ in each plot and grain yield adjusted to $14 \%$ moisture content and, then, converted into t/ha. Quality of rice grains are defined by the physical appearance, cooking and eating qualities. Grain characteristics of rice grain were determined at the grain quality laboratories of the RRTC as follows: physical appearance (Grain length, width and shape (L/W ratio)) and milling recovery (hulling, milling and head rice \%) were measured, according to the method described by Juliano (1971), Khush et al., (1979) and IRRI (1996). Amylose is one of the starches, and in rice, the amount of amylose ranges from $0 \%$ to $30 \%$. Commonly, the Egyptian rices are low amylose, ranging from about 17-20\%. Amylose content was determined byautoanalyzer based on the iodine-colorimetric method Juliano (1971). Gel consistency measures the tendency of the cooked rice to harden on cooling. It was determined according to the test of Cagampang et al., (1973). Gelatinization temperature is the temperature at which the starch in rice begins the process of cooking. At this point the starch granules take in water and lose their crystalline nature, a change that is irreversible. Temperature of gelatinization process was distinguished Little et al., (1958).

The analysis of variance was carried out according to Gomez and Gomez (1984) using GENSTAT $5^{\text {th }}$ Edition Computer Program. Means were compared, using the least significant differences (LSD) at $5 \%$ probability level. 
Table (1): Monthly temperature means, relative humidity (RH) and pan evaporation (E) at the experimental site during growth period.

\begin{tabular}{|c|c|c|c|c|c|c|c|c|c|c|}
\hline \multirow{3}{*}{ Month } & \multicolumn{5}{|c|}{2016} & \multicolumn{5}{|c|}{2017} \\
\hline & \multicolumn{2}{|c|}{$\begin{array}{c}\text { Air temperature } \\
\left({ }^{\circ} \mathrm{C}\right)\end{array}$} & \multicolumn{2}{|c|}{ RH \% } & \multirow{2}{*}{$\begin{array}{c}\mathrm{E} \\
\text { (mm/ } \\
\text { day) }\end{array}$} & \multicolumn{2}{|c|}{$\begin{array}{c}\text { Air temperature } \\
\left({ }^{\circ} \mathrm{C}\right)\end{array}$} & \multicolumn{2}{|c|}{$\mathrm{RH} \%$} & \multirow{2}{*}{$\begin{array}{c}\mathrm{E} \\
(\mathrm{mm} / \\
\text { day })\end{array}$} \\
\hline & Max. & Mini. & $7: 30$ & $13: 30$ & & Max. & Mini. & $7: 30$ & $13: 30$ & \\
\hline April & 30.3 & 18.62 & 81.6 & 41.8 & 5.94 & 26.5 & 21.6 & 79.4 & 50.8 & 4.64 \\
\hline May & 30.4 & 22.8 & 71.0 & 45.8 & 6.47 & 30.6 & 25.8 & 77.7 & 45.6 & 6.59 \\
\hline June & 33.6 & 26.3 & 75.7 & 46.6 & 8.07 & 32.5 & 28.1 & 80.1 & 51.4 & 7.10 \\
\hline July & 33.7 & 26.1 & 82.7 & 65.8 & 7.84 & 34.2 & 29.0 & 84.4 & 57.6 & 6.44 \\
\hline August & 33.6 & 26.0 & 84.3 & 56.3 & 7.74 & 33.9 & 28.3 & 85.9 & 55.3 & 6.04 \\
\hline September & 32.6 & 24.3 & 83.1 & 51.8 & 5.91 & 32.5 & 25.9 & 86.3 & 50.3 & 5.37 \\
\hline
\end{tabular}

\section{RESULTS AND DISCUSSION Experiment (1): Effect of different dates of planting. \\ I-Days to $50 \%$ heading, plant height, grain yield and its attributes:}

The results in Table 2 show that the number of days to $50 \%$ heading, plant height, grain yield and its attributes were significantly affected by the planting dates. Days to $50 \%$ heading, which is an indicator of maturity time, was significantly decreased in case of delayed planting. Early planting date of $20^{\text {th }} \mathrm{April}$ spent the longest duration to attain $50 \%$ heading, however, late

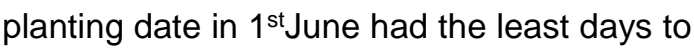
attain 50\% heading. Heo et al., (2017) reported that the whole growth period of rice was shortened with the delay of sowing date. There was a decreasing trend in plant height, particularly when planting was delayed beyond May $10^{\text {th }}$. The sowing dates $20^{\text {th }}$ April, $1^{\text {st }}$ May and $10^{\text {th }}$ May produced the maximum plant height, Table 2 . The lowest plant height was produced from the last sowing date (1st June). Sowing dates from $20^{\text {th }}$ April to $10^{\text {th }}$ May produced statistically similar and tallest plant heights, while late sowing $\left(20^{\text {th }}\right.$ May and $1^{\text {st }}$ June) they produced statistically different plant heights. Rai and Kushwaha (2008) observed that the delay in planting decreased plant height $(13 \%)$, number of days to $50 \%$ flowering (12 to 15 days). Safdar et al., (2013) found that days to $100 \%$ flowering were found having decreasing trend in all accessions due to delayed sowing. Also, plant height seems to be downward as their sowing times were delayed.

The grain yield attributes are the most important parameters of any crop which directly influence the crop yield. Late in planting caused a remarkable reduction in most of grain yield attributes, Table 2. In both seasons, early planting date $\left(20^{\text {th }} \mathrm{April}\right)$ and medium planting dates $\left(1^{\text {st }}\right.$ and $10^{\text {th }}$ of May) gave the highest values of number of panicles, panicle length, no. of grains/panicle, panicle weight and 1000 grain weight. However, late in planting $\left(20^{\text {th }}\right.$ May and $1^{\text {st }}$ June) significantly reduced all previous traits, but gave the highest unfilled grains percentage. Improvement in these parameters can be better explained by the fact that the crop planted from $20^{\text {th }}$ April to $10^{\text {th }}$ May received optimum environmental conditions required for better growth and development. Abou-Khalifa (2009) indicated that early date of sowing is the best time for important properties such as number of grains panicle ${ }^{-1}$, panicle length, 1000-grain weight, number of panicles $\mathrm{m}^{-2}$, panicle weight and grain yield. 
Table (2): Days to $50 \%$ heading, plant height, grain yield and its attributes of Giza $\mathbf{1 7 9}$ rice cultivar as affected by planting dates in 2016 and 2017 seasons.

\begin{tabular}{|c|c|c|c|c|c|c|c|}
\hline \multirow[b]{2}{*}{ Season } & \multirow[b]{2}{*}{ Character } & \multicolumn{5}{|c|}{ Planting date } & \multirow{2}{*}{$\begin{array}{l}\text { LSD } \\
5 \%\end{array}$} \\
\hline & & $\begin{array}{l}21 \\
\text { Aril }\end{array}$ & $\begin{array}{c}1 \\
\text { May }\end{array}$ & $\begin{array}{c}10 \\
\text { May }\end{array}$ & $\begin{array}{c}20 \\
\text { May }\end{array}$ & $\begin{array}{c}1 \\
\text { June }\end{array}$ & \\
\hline \multirow[t]{10}{*}{2016} & Days to $50 \%$ heading & 96.25 & 94.75 & 94.25 & 93.00 & 92.50 & 1.51 \\
\hline & Plant height $(\mathrm{cm})$ & 90.25 & 89.50 & 88.50 & 83.75 & 81.00 & 3.28 \\
\hline & No. of panicles $/ \mathrm{m}^{2}$ & 489.8 & 488.8 & 478.8 & 427.5 & 381.3 & 46.5 \\
\hline & Panicle length $(\mathrm{cm})$ & 20.10 & 19.80 & 19.48 & 18.85 & 18.42 & 1.05 \\
\hline & No. of grains/panicle & 125.6 & 122.8 & 120.1 & 102.0 & 80.9 & 4.6 \\
\hline & Unfilled grain (\%) & 4.43 & 4.76 & 5.22 & 6.81 & 8.39 & 0.94 \\
\hline & Panicle weight (g) & 2.96 & 2.84 & 2.64 & 2.25 & 2.02 & 0.42 \\
\hline & 1000-grain weight (g) & 24.82 & 25.77 & 25.60 & 24.66 & 23.50 & 1.28 \\
\hline & Grain yield (t/ha) & 11.79 & 12.58 & 12.68 & 10.58 & 9.55 & 0.87 \\
\hline & Straw yield (t/ha) & 15.18 & 14.75 & 14.58 & 12.70 & 10.88 & 1.10 \\
\hline \multirow[t]{10}{*}{2017} & Days to $50 \%$ heading & 98.50 & 97.50 & 97.00 & 94.75 & 92.50 & 1.16 \\
\hline & Plant height $(\mathrm{cm})$ & 91.95 & 91.45 & 89.85 & 84.60 & 78.60 & 2.47 \\
\hline & No. of panicles $/ \mathrm{m}^{2}$ & 463.8 & 462.5 & 451.3 & 411.3 & 324.4 & 50.7 \\
\hline & Panicle length $(\mathrm{cm})$ & 18.85 & 19.43 & 19.30 & 18.63 & 16.70 & 0.92 \\
\hline & No. of grains/panicle & 116.2 & 114.0 & 112.5 & 104.7 & 80.3 & 10.6 \\
\hline & Unfilled grain (\%) & 5.58 & 5.85 & 6.28 & 6.95 & 6.78 & 1.02 \\
\hline & Panicle weight (g) & 2.86 & 2.96 & 2.61 & 2.22 & 1.99 & 0.33 \\
\hline & 1000-grain weight (g) & 25.62 & 25.30 & 25.42 & 25.05 & 23.80 & 0.96 \\
\hline & Grain yield (t/ha) & 11.75 & 12.04 & 12.10 & 10.81 & 9.38 & 0.80 \\
\hline & Straw yield (t/ha) & 14.05 & 13.60 & 13.80 & 12.90 & 11.45 & 0.97 \\
\hline
\end{tabular}

NS = Not significant

These results, also, indicated that exposing rice plant to late planting caused significant reduction in grain and straw yields, this held true since all yield attributes were affected by such conditions. There isn't any significant difference among the three dates of planting $\left(21^{\text {st }}\right.$ April, $1^{\text {st }}$ May and $10^{\text {th }}$ May) in the two seasons of study. Grain yield increased with delay of sowing date until reached the peak grain yield values which achieved at $10^{\text {th }}$ May. The third sowing of rice (10 $10^{\text {th }}$ May) gave the maximum grain yield (12.68 and $12.10 \mathrm{t} / \mathrm{ha}$ ), followed by $1^{\text {st }}$ May sowing ( 12.58 and $12.04 \mathrm{t} / \mathrm{ha}$ ) and then early sowing date of $20^{\text {th }}$ April (11.79 and 11.75 t/ha). The significant lowest grain yield (9.55 and $9.38 \mathrm{t} / \mathrm{ha}$ ) were noted from $1^{\text {st }}$ June sowing, in the two successive seasons. Results showed that in first, second and third planting dates because of appropriate growth condition and reaching to maximum use of environmental condition, most grain yield was produced. It is the fact that the unavailability of weather condition inhibits the production of dry matter content in the different plant organs beside number of panicles $/ \mathrm{m}^{2}$, number of filled grains/panicle and grain yield. The grain yield reductions might be due to reduction in vegetative growth period on account of delayed sowing. Alizadeh and Osivand (2006), announced a delay in sowing rice, shorten vegetative phase and reducing the accumulation of carbohydrates and minerals in different organs and subsequent spike length and grain yield decreased. The yield reductions under later sowing dates have been reported by Singh 
et al., (2012), Tiwari (2015) and Osman et al., (2015).

The sowing dates exerted significant influence upon straw yield. Accordingly, among the sowing dates, earliest $20^{\text {th }} \mathrm{April}$ sowing recorded maximum straw yield (15.18 and $14.05 \mathrm{t} / \mathrm{ha}$ ), closely followed by $1^{\text {st }}$ May and $10^{\text {th }}$ May sowing. The significant lowest straw yield (10.88 and $11.45 \mathrm{t} / \mathrm{ha}$ ) were recorded from late sowing date $1^{\text {st }}$ June in both seasons, respectively. Similar finding were reported by Rai and Kushwaha (2008) and Tiwari (2015).

\section{II- Grain quality:}

Rice quality is a combination of physical and chemical characteristics which are required for a specific use by a specific user.

\section{A- Physical appearance characters.}

Most of the farmers and consumers depend mainly on visual characters for differentiation and evaluation of rice varieties. Grain length is measured from the base to the top of the milled grains. The length and width of a rice grain are important attributes that determine the class of the rice. The ratio of the length and width is used internationally to describe the shape and class of the variety. Milled rice is classified on the basis of average length into four classes: short, medium, long, and extra long. Grain length was significantly affected by different planting date (Table 3). Grain length increased with delayed planting date upto $20^{\text {th }}$ May and thereafter, declined. The longest grain (5.78 and $5.66 \mathrm{~mm}$ ) was observed when rice plants were planted in $20^{\text {th }}$ May and the shortest grain (5.27 and $5.21 \mathrm{~mm}$ ) from early planting in $20^{\text {th }}$ April, in the two respective seasons. In both seasons, grain width was not influenced up to significant extent due to different dates of planting. However, grain shape was significantly responded to different planting date only in first season Table 3. The highest value was recorded when plants were planted in $20^{\text {th }}$ May as compared with other planting dates, however, the lowest value was obtained in planting date of $1^{\text {st }}$ May.

\section{B- Milling recovery characters.}

Data regarding hulling, milling and head rice percentage had significant differences due to different planting dates, Table 3 . Generally results showed increasing trends for hulling percentage with delayed planting reaching the maximum value (79.41 and $77.33 \%)$ at third date (10 $10^{\text {th }}$ May) thereafter declined to give the minimum value (76.75 and $75.95 \%$ ) with delayed planting up to $1^{\text {st }}$ June, in the two respective seasons. The data, also, showed that milling percentage gradually increased with the delaying of planting date. In both seasons, the lowest percent of milling (66.15and $65.11 \%$ ) was given by the early sowing date at April $20^{\text {th }}$. On the other hand, the late planting date at June $1^{1^{\text {st}}}$ was resulted in obtaining high percent of milling (70.47 and $70.22 \%$ ).

Head rice percentage gradually increased with delaying planting, where, the maximum value was obtained with planting dates at $10^{\text {th }}$ May $(62.92 \%)$, in first season, and with planting date at $20^{\text {th }}$ May $(63.44 \%)$, in second season. However, the lowest percentage was observed for the sowing date $1^{\text {st }}$ June in both seasons. The head rice reductions might be due to higher temperature and unavailability of weather condition, during grain filling, recorded in delay planting resulted in low head rice recovery and higher broken rice. Both delayed and early planting dates resulted in the decline of milling quality of rice. The reason for these reductions was the shortening of the vegetative growth period in the case of delayed planting, and the coincidence of the flowering stage with environmental high temperatures in earlier planting dates compared to the desirable state. Jia- gou et al., (2003) found that the grain quality interrelated to the grain filling degree. It was better to keep water in paddy until 25 days after $80 \%$ of full heading for rice quality cultivation. 
Table (3): Physical, milling, cooking and eating quality characters of Giza 179 rice cultivar as affected by planting dates in 2016 and 2017 seasons.

\begin{tabular}{|c|c|c|c|c|c|c|c|}
\hline \multirow{3}{*}{ Season } & \multirow{3}{*}{ Character } & \multicolumn{5}{|c|}{ Planting date } & \multirow{3}{*}{$\begin{array}{c}\text { LSD } \\
5 \%\end{array}$} \\
\hline & & 20 & 1 & 10 & 20 & 1 & \\
\hline & & Aril & May & May & May & June & \\
\hline \multirow[t]{12}{*}{2016} & Physical characteristics & & & & & & \\
\hline & Grain length (mm) & 5.21 & 5.27 & 5.46 & 5.78 & 5.59 & 0.17 \\
\hline & Grain width (mm) & 2.53 & 2.63 & 2.72 & 2.59 & 2.60 & NS \\
\hline & Grain shape & 2.07 & 2.00 & 2.01 & 2.23 & 2.15 & 0.19 \\
\hline & Milling quality & & & & & & \\
\hline & Hulling (\%) & 78.19 & 79.00 & 79.41 & 76.65 & 76.75 & 1.34 \\
\hline & Milling (\%) & 66.15 & 66.30 & 67.00 & 68.59 & 70.47 & 2.55 \\
\hline & Head rice (\%) & 57.77 & 60.00 & 62.92 & 59.92 & 57.42 & 2.59 \\
\hline & Cooking and eating quality & & & & & & \\
\hline & Amylose content & 18.27 & 18.46 & 17.49 & 17.16 & 17.15 & 1.03 \\
\hline & Gel consistency & 87.65 & 87.49 & 87.78 & 87.16 & 87.26 & NS \\
\hline & Gelatinization temperature & 6.00 & 6.50 & 6.50 & 5.75 & 5.75 & NS \\
\hline \multirow[t]{12}{*}{2017} & Physical characteristics & & & & & & \\
\hline & Grain length (mm) & 5.27 & 5.28 & 5.44 & 5.66 & 5.45 & 0.15 \\
\hline & Grain width (mm) & 2.57 & 2.60 & 2.66 & 2.61 & 2.60 & NS \\
\hline & Grain shape & 2.05 & 2.03 & 2.04 & 2.16 & 2.10 & NS \\
\hline & Milling quality & & & & & & \\
\hline & Hulling (\%) & 76.93 & 77.11 & 77.33 & 76.44 & 75.97 & 1.49 \\
\hline & Milling (\%) & 65.11 & 66.67 & 66.22 & 68.00 & 70.22 & 1.57 \\
\hline & Head rice (\%) & 59.37 & 59.89 & 62.63 & 63.44 & 57.88 & 3.20 \\
\hline & Cooking and eating quality & & & & & & \\
\hline & Amylose content & 18.65 & 18.34 & 18.06 & 17.97 & 17.78 & 0.56 \\
\hline & Gel consistency (mm) & 88.07 & 87.70 & 87.42 & 87.31 & 87.31 & NS \\
\hline & Gelatinization temperature & 6.25 & 6.50 & 6.25 & 6.00 & 6.00 & NS \\
\hline
\end{tabular}

NS = Not significant

\section{C-Cooking and eating quality characters.}

Amylose content is a major determinant of cooking and eating quality characters of rice. It is considered to be the key factor that contributes to the cooking quality of rice grains. Planting dates had significant effects on amylose content, but there was no effect on gel consistency and gelatinization temperature, in both seasons, Table 3 . The temperature during grain ripening has been showed a remarkable effect on the amylose content. Generally, it decreased as the mean temperature increased, depending on the variety and inherent level of amylose content. Amylose content decreased slightly with delayed planting date, although that, it is still in low amylose content.

Generally, environmental factors like temperature, photoperiod and relative humidity have been documented to have little effect on the width of grains, gel consistency and gelatinization temperature compared with that on grain length, grain shape, milling recovery and amylose content. Singh et al., (1995) reported that late sowing date gave maximum hulling and 
head rice percentage while, it decreased the milling $\%$ and amylose content. Delaying sowing date decreased the percentage of milling, head rice and amylose content. Xing et al., (2016) found that the appearance quality was ameliorated when the sowing date was postponed. Also, the postponement of sowing date reduced the amylase content and shortened the gel consistency. These current results were in agreement with the findings of Heo et al., (2017).

\section{Experiment (2): Effect of different dates of irrigation termination: \\ I- Plant height, grain yield and its attributes:}

plant height, number of panicles $/ \mathrm{m}^{2}$ and panicle length were not significantly influenced by the dates of irrigation termination studies, due to compete its growth by the time of last irrigation and suspended at complete heading, Table 4 . The grain yield and its attributes (number of grains/panicle, panicle grain weight and 1000-grain weight) were significantly increased with delay in withholding of irrigation compared with earlier cut-off dates of irrigation in both seasons except straw yield in first season. On the other hand, unfilled grains percentage was decreased. The grain yield was found to be maximum under termination of irrigation at $20 \mathrm{DACH}$ (11.98 and $11.89 \mathrm{t} / \mathrm{ha}$ ) followed by withholding of irrigation at $25 \mathrm{DACH}$ (11.77 and $11.34 \mathrm{t} / \mathrm{ha}$ ) and then $15 \mathrm{DACH}$, without significant differences among the last three treatments in first season and between the last two treatments in second season. The comparatively lower grain under early withholding irrigation might be significantly attributed to lesser panicle length, grains per panicle and numerically less panicles $/ \mathrm{m}^{2}$ resulted from shorter supply of moisture at ripening stage than 20 and $25 \mathrm{DACH}$. Also, the increase in grain yield attributes, with delayed irrigation termination, was the reason for the increase grain yield in $20 \mathrm{DACH}$ treatment. The results, also, indicates that under early termination of irrigation, the carbohydrates stored in the lower vegetative parts get less translocated to grains, when the concurrent insufficient for photosynthates-sink in the grain owing to plant-water deficit and then, decreased the grain yields.

However, continuing irrigation up to 20 $\mathrm{DACH}$ might have improved the translocation of the current photosynthates and resulted in higher grain filling process thereby, increased grain yield. The results are in conformity with the findings of Uppal and Bali (1994), El-Refaee (2007), Brar et al., (2009) and Omar et al., (2012).

\section{II- Grain quality:}

Grain quality of rice refers to many characters such as physical appearance, milling recovery, cooking and eating quality. Those characters are considered as the most important traits that affected rice quality and consumer demand.

\section{A- Physical appearance characters:}

Length and width of rough grains were responded significantly due to cut-off irrigation treatments. Where the ceiling length and width produced at 15 and 20 $\mathrm{DACH}$ without any significant differences between each other in both seasons of study. Whereas, the grain shape was statistically the same with different dates of withholding irrigation in both seasons, Table 5. Cut-off irrigation early at complete heading recorded the minimum values of grain length and width as compared with the other irrigation termination in two seasons. The results are in agreement with those obtained by El-Refaee (2007).

\section{B- Milling recovery characters:}

Results in Table 5 indicated that cut off water irrigation at $20 \mathrm{DACH}$ significantly increased hulling, milling and head rice recovery of rice grains than early withholding irrigation at complete heading. The milling recovery with delay irrigation withholding 
beyond $15 \mathrm{DACH}$ was high due to the corresponding increase in the moisture content of the grain. However, lower milling recovery in the treatment receiving last irrigation immediately at complete heading and $5 \mathrm{DACH}$ might be due to early drying of the grains before completion of ripening. The results are in conformity with the findings of Uppal and Bali (1994), El-Refaee (2007) and Omar et al., (2012).

Delaying last irrigation up to 20 and 25 $\mathrm{DACH}$ resulted in higher head rice recovery, however, in early irrigation withholding at heading the moisture content in grain was low and broken rice recovery was high. Besides, delaying harvesting (for the first three treatments) along with other alternative treatments may resulting low moisture content in grain during day and in night some amount of moisture is re-absorbed by the deposition of dew. Such circumstances as alternate drying and wetting cycles cause mechanical stress which may resulted in the development of fissures and ultimately in higher percentage of broken rice. The less head rice recovery under early withholding irrigation might be ascribed to incomplete grain filling due to impairment of current photosynthesis and translocation of assimilates towards sink. This may have increased number of chalky grains, which got broken during processing. Bali (1992) also recovered significantly less head rice from scented rice under early suspension of irrigation at 7 and 14 days after $50 \%$ flowering than delayed at 21 days after $50 \%$ flowering.

Table (4): Days to $50 \%$ heading, plant height, grain yield and its attributes of Giza $\mathbf{1 7 9}$ rice cultivar as affected by irrigation termination dates in 2016 and 2017 seasons.

\begin{tabular}{|c|c|c|c|c|c|c|c|c|}
\hline \multirow[t]{2}{*}{ Season } & \multirow[t]{2}{*}{ Character } & \multicolumn{6}{|c|}{$\begin{array}{l}\text { Irrigation termination date } \\
\text { (days after complete heading) }\end{array}$} & \multirow{2}{*}{$\begin{array}{c}\text { LSD } \\
5 \%\end{array}$} \\
\hline & & 0 & 5 & 10 & 15 & 20 & 25 & \\
\hline \multirow[t]{9}{*}{2016} & Plant height $(\mathrm{cm})$ & 89.30 & 89.53 & 91.62 & 90.10 & 90.25 & 89.70 & NS \\
\hline & No. of panicles $/ \mathrm{m}^{2}$ & 437.5 & 466.5 & 443.1 & 486.0 & 445.8 & 448.8 & NS \\
\hline & Panicle length $(\mathrm{cm})$ & 20.16 & 21.00 & 20.17 & 20.85 & 20.80 & 19.50 & NS \\
\hline & No. of grains/panicle & 110.90 & 127.25 & 133.30 & 136.25 & 137.00 & 127.00 & 9.42 \\
\hline & Unfilled grain (\%) & 13.00 & 8.40 & 7.15 & 5.35 & 4.65 & 4.92 & 3.49 \\
\hline & Panicle weight (g) & 2.64 & 2.86 & 2.93 & 3.13 & 3.23 & 3.00 & 0.36 \\
\hline & 1000-grain weight (g) & 24.45 & 26.87 & 26.75 & 27.17 & 27.20 & 27.88 & 1.44 \\
\hline & Grain yield (t/ha) & 6.97 & 7.28 & 9.79 & 11.08 & 11.98 & 11.77 & 0.93 \\
\hline & Straw yield (t/ha) & 14.17 & 14.78 & 14.92 & 15.09 & 15.02 & 14.94 & NS \\
\hline \multirow[t]{9}{*}{2017} & Plant height $(\mathrm{cm})$ & 88.67 & 88.95 & 88.00 & 90.85 & 89.95 & 89.20 & NS \\
\hline & No. of panicles $/ \mathrm{m}^{2}$ & 423.8 & 402.5 & 447.5 & 412.5 & 413.8 & 406.3 & NS \\
\hline & Panicle length $(\mathrm{cm})$ & 19.70 & 19.85 & 19.40 & 20.60 & 18.85 & 18.85 & NS \\
\hline & No. of grains/panicle & 117.80 & 122.15 & 124.40 & 127.30 & 129.15 & 123.75 & 6.80 \\
\hline & Unfilled grain (\%) & 13.48 & 10.20 & 5.10 & 5.08 & 5.65 & 4.40 & 2.14 \\
\hline & Panicle weight (g) & 2.42 & 2.66 & 2.86 & 3.18 & 3.29 & 3.02 & 0.38 \\
\hline & 1000-grain weight (g) & 24.77 & 25.00 & 25.22 & 25.95 & 26.37 & 26.52 & 0.87 \\
\hline & Grain yield (t/ha) & 6.46 & 7.35 & 9.11 & 10.90 & 11.89 & 11.34 & 0.95 \\
\hline & Straw yield (t/ha) & 13.53 & 14.56 & 15.10 & 15.31 & 15.14 & 15.00 & 1.14 \\
\hline
\end{tabular}

NS = Not significant 
Table (5): Physical, milling, cooking and eating quality characteristics of Giza 179 rice cultivar as affected by irrigation termination in 2016 and 2017 seasons.

\begin{tabular}{|c|c|c|c|c|c|c|c|c|}
\hline \multirow[t]{2}{*}{ Season } & \multirow[t]{2}{*}{ Character } & \multicolumn{6}{|c|}{$\begin{array}{c}\text { Irrigation termination date } \\
\text { (days after complete heading) }\end{array}$} & \multirow{2}{*}{$\begin{array}{r}\text { LSD } \\
5 \%\end{array}$} \\
\hline & & 0 & 5 & 10 & 15 & 20 & 25 & \\
\hline \multirow[t]{12}{*}{2016} & Physical characteristics & & & & & & & \\
\hline & Grain length (cm) & 5.27 & 5.41 & 5.56 & 5.74 & 5.72 & 5.66 & 0.22 \\
\hline & Grain width $(\mathrm{cm})$ & 2.41 & 2.52 & 2.64 & 2.68 & 2.61 & 2.66 & 0.17 \\
\hline & Grain shape & 2.19 & 2.15 & 2.11 & 2.15 & 2.20 & 2.13 & NS \\
\hline & Milling quality & & & & & & & \\
\hline & Hulling (\%) & 67.42 & 77.52 & 78.67 & 78.77 & 79.25 & 79.00 & 1.50 \\
\hline & Milling (\%) & 62.67 & 67.00 & 68.28 & 69.00 & 69.65 & 69.75 & 1.91 \\
\hline & Head rice (\%) & 50.15 & 54.53 & 57.05 & 61.65 & 63.83 & 63.25 & 3.46 \\
\hline & Cooking and eating quality & & & & & & & \\
\hline & Amylose content & 19.13 & 19.06 & 18.87 & 18.31 & 18.08 & 17.76 & 0.58 \\
\hline & Gel consistency & 91.56 & 90.56 & 89.95 & 89.03 & 88.21 & 88.19 & 0.39 \\
\hline & Gelatinization temperature & 6.75 & 6.50 & 7.00 & 6.50 & 6.50 & 6.00 & NS \\
\hline \multirow[t]{12}{*}{2017} & Physical characteristics & & & & & & & \\
\hline & Grain length (cm) & 5.36 & 5.41 & 5.50 & 5.62 & 5.62 & 5.60 & 0.18 \\
\hline & Grain width (cm) & 2.46 & 2.57 & 2.65 & 2.67 & 2.68 & 2.67 & 0.13 \\
\hline & Grain shape & 2.19 & 2.11 & 2.07 & 2.11 & 2.10 & 2.10 & NS \\
\hline & Milling quality & & & & & & & \\
\hline & Hulling (\%) & 73.50 & 75.70 & 76.30 & 77.82 & 78.32 & 78.40 & 1.24 \\
\hline & Milling (\%) & 64.87 & 66.04 & 67.35 & 69.01 & 69.52 & 69.47 & 2.52 \\
\hline & Head rice (\%) & 47.97 & 53.97 & 57.63 & 62.15 & 62.83 & 62.95 & 2.90 \\
\hline & Cooking and eating quality & & & & & & & \\
\hline & Amylose content & 18.89 & 19.20 & 18.94 & 18.84 & 17.76 & 17.66 & 0.59 \\
\hline & Gel consistency $(\mathrm{mm})$ & 92.01 & 90.53 & 89.84 & 88.91 & 88.27 & 88.11 & 0.48 \\
\hline & Gelatinization temperature & 6.50 & 6.50 & 6.75 & 6.25 & 6.50 & 6.25 & NS \\
\hline
\end{tabular}

C- Cooking and eating quality:

Amylose content and gel consistency were significantly responded by varying water termination treatments. However, gelatinization temperature was not significantly influenced with respect to withholding irrigation treatments during both the years Table 5. In first season, the maximum amylose content was produced in case of treatments 0 DACH (19.13\%) followed by $5 \mathrm{DACH}(19.06 \%)$ and $10 \mathrm{DACH}$ $(18.87 \%)$. While, in the second season the maximum amylose content was obtained by treatment of $5 \mathrm{DHCH}(19.20 \%)$ followed by
$10 \mathrm{DACH}(18.94 \%)$ and $0 \mathrm{DACH}(18.89 \%)$ which were statistically at par with each other. The other treatments produced significantly lesser amylose content, whereas, the minimum values of amylose content (17.76 and $17.66 \%)$ were obtained by withholding irrigation at 25 days after complete heading, in the two respective seasons. This is due to the fact that moisture stress increases amylose content of grains and there is a negative correlation of amylose content in the rice grains under moisture stress conditions Fofana et al. (2010). Although the significant in amylose 
content, it is still in low amylose content category. The results are in conformity with the findings of Omar et al., (2012) and Choudhary (2016). High values of gel consistency (91.56 and 92.01) were associated with early cut-off irrigation at $\mathrm{ACH}$, and gel consistency gradually declined to reach the lowest values (88.19 and 88.11) at later cut-off irrigation dates at $25 \mathrm{DACH}$, in the two respective seasons.

Finally, it could be concluded that a planting date of $1^{\text {st }}$ and $10^{\text {th }}$ May might enable to achieve high grain yield for Giza 179 rice cultivar. However, delayed planting up to $20^{\text {th }}$ May achieve acceptable grain quality. On the other hand, maximum grain yield combined with high grain quality seem to be associated with delaying water termination up to 20 days after complete heading.

\section{REFERENCES}

Abou-Khalifa, A. B. (2009). Physiological evaluation of some hybrid rice varieties under different sowing dates. Austr. J.o of Cro. Sci. 3(3):178-183.

Alizadeh, M. and H. Osivand (2006). Rice in Egypt. Publishing Office, Department of Agriculture, Ministry of Agriculture, rice and beans. $540 \mathrm{pp}$.

Bali, A. S. (1992). Growth and yield dynamics of Basmati rice (Oryza sativa L.) relation to irrigation schedules and planting dates.' Ph. D thesis Punjab Agricultural University, Ludhiana, India.

Bashir, M. U., N. Akbar, A. Iqbal and H. Zaman (2010). Effect of different sowing dates on yield and yield components of direct seeded coarse rice (Oryza sativa L.) Paki. J. of Agri. Sci. 47(4): 361-365.

Brar, A. S., S. S. Mahal and Neerja Sharma (2009). Yield and quality characters of basmati rice (Oryza sativa) under three cut-off date of irrigation. Ind. J. of Agri. Sci. 79 (3): 215-17.

Cagampang, B.G., C.M. Perez and B.O. Juliano (1973). A gel consistency test for eating quality rice. J. Sci. Fd. Agri. 24: 1589-1594.

Choudhary, K. (2016). Effect of irrigation scheduling on growth, yield and quality of direct seeded basmati rice (Oryza sativa L.) varieties. M.Sc. Thesis, Div. Agron. Sher-e-Kashmir Univ. Agric. Sci. \& Tech., Jammu, India.

Dinesh, C., K. Lodh, M. Sahoo, B. B. Nanda and D. Chander (1997). Effect of date of planting and spacing on grain yield and quality of scented rice (Oryza sativa) varieties in wet season in coastal. Orissa Ind. J. of Agri. Sci. 67:93-97.

El-Refaee, I. S. (2007). Effect of cut-off irrigation date on grain yield and quality of some Egyptians rice cultivars. J. Agric. Res. Kafr El-Sheikh Univ., 33 (1): 123139.

Fofana, M., M. Cherif, B. Kone, K. Futakuchi and A. Audebert (2010). Effect of water deficit at grain repining stage on grain quality. J. Agric. Biotech. and Sust. Develop., 2: 100-107.

Gomez, K.A. and A.A. Gomez (1984). Statistical Procedures for Agricultural Researches. $2^{\text {nd }}$ Ed., John Wiley \& Sons. U.S.A.

Groth, D. E. and F. N. Lee (2003). Rice diseases. In C.W. smith and R.H. Dilday (ed.) Rice: Origin, history, technology, and production. John Wiley and sons, Hoboken, New Jersey, 413-436.

Haider, Z., U. Farooq, I. Naseem, S. Zia and M. Alamgeer (2015). Impact of drought stress on some grain quality traits in rice (Oryza sativa). Nati. Acad. of Agri. Sci., 4(2):132-138.

Heo, W., L. H. Yu, Y. Zhen Xie and Z. Tie Jun (2017). Effects of sowing date on grain yield and quality of purple rice. $J$. China Rice, 23(4): 165-167.

IRRI (International Rice Research Institute) (1996). Standard evaluation System for Rice. IRRI, P.O. Box 933, 1099 Manila, Philippines.

Jia-guo, Z., R. Guang-jun, L. Xian-jun and J. Xin-lu (2003). Effect of water stress on rice grain yield and quality after heading 
stage. Chinese J. Rice Sci., 17(3): 239243.

Juliano, B.O. (1971). A simplified assay for milled rice amylose. Cereal Sci. Today (16): 334-338,340-360.

Khush, G. S., C. M. Paule and Dela Cruz (1979). Rice grain quality evaluation and improvement at IRRI. Proc. Workshop on Chemical Aspects of Rice Grain Quality, 16(5): 28.

Little, R.R., G.B. Hilder and E.H. Dowson (1858). Differential effect of dilute alkali on 25 varieties of milled white rice. Cereal Chem. 35: 111-126.

Liu Y, D. Gu, Y. Ding, Q. Wang, G. Li and S. Wang (2011). The relationship between nitrogen, auxin and cytokinin in the growth regulation of rice (Oryza sativa L.) tiller buds. Austr. J. of Crop Sci. 5(8),1019-1026.

Omar, A. M., I. S. El-Refaee and H. A. Ghazy (2012). Behavior of Egyptian hybrid rice cultivar (EHR1) under different irrigation regimes and harvesting times. J. Plant Prod. Mansoura Univ., 3(3): 463478.

Osman, K. A., A. M. Mustafa, Y. M. A. Elsheikh and A. E. Idris (2015). Influence of different sowing dates on growth and yield of seeded rice (Oryza sativa L.) in semi-arid zone (Sudan). Inter. J. of Agro. and Agri. Res. (IJAAR), 6 (6): 38-48.

Rani, M. and H. S. Kushwah (2008). Effect of planting dates, irrigation schedules and nitrogen dozes on performance of scented rice (Oryza sativa L.) Pantnagar J. of Res. 6(2):257-260.

Rousset, S., B. Pons and J. N. Martin (1999). Identifying objective characteristics that product clusters produced by sensory attributes in cooked rice. J. Texture Stud. 30:50-532.

Safdar, M. E., I. R. Noorka, A. Tanveer, S. A. Tariq and S. Rauf (2013). Growth and yield of advanced breeding lines of medium grain rice as influenced by different transplanting dates. J. Anim. Plant Sci. 23(1): 227-231.

Singh, A. K., N. Chandra and R. C. Bharti (2012). Effects of genotype and planting time on phonology and performance of rice (Oryza sativa L.). Ind. J. of Agro. 25(1):151-156.

Singh, S. P., K. G. Pillai, D. Pat and N. S. Rani (1995). Effect of planting date on grain yield and quality of semi-dwarf scented rice varieties. Int. Rice Res. Newsletter, 20 (1): 24-25.

Slaton, N.A. (2001). Rice production hand book. Misc. Publ., 192. Arkansas coop. Ext. service, University of Arkansas, Little Rock, AR.P, 281.

Swaminathan, M. S. (2007). Can the science and technology feed the world in 2025? Field Crop Res., 104:3-9.

Tiwari, P. (2013). Effect of sowing dates on performance of different rice varieties under upland condition. M.Sc. Thesis, Agric. College, Rewa (M.P.) J.N.K.V.V. Jabalpur (M.P.) Univ., India.

Uppal, H. S. and A. S. Bali (1994). Effect of scheduling and cut-off date of irrigation on yield and quality of rice (Oryza sativa) in a non-cracking soil. Ind. J. Agron., 39 (4):628-630.

Veronic, V., P. Brigitte, B. Judith, H. Stephan, R. Xavier and M. Christian (2007). Cooking behavior of rice in Relation to Kernel Physicochemical Properties. J. Agri. Food Chem. 55:336346.

Xing, Z., W. Cao, H. Qian, Y. Hu, H. Zhang, Q. Dai, Z. Huo and K. Xu (2016). Effect of sowing date on the formation of quality of mechanically transplanting rice in ricewheat cropping areas. China J. of Ecol., 35(1):1-10.

Yoshida, S. (1981). Fundamentals of rice crop sciences. IRRI., Los Banas, Philippines. pp. 269. 
تأثير مواعيد الزراعة والفطام على الإنتاجية وجودة الحبوب لصنف الأرز جيزة 179

\section{وائل حمدي محرم الكلاوى}

مركز البحوث الزراعية- معهة بحوث المحاصيل الحقلية- مركز البحوث والتدريب فى الأرز - سخا- كفر الثيخ

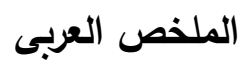

تعتبر مواعيد الزراعة ونظم توقف الري من الجوانب الهامة فى نجاح إنتاج الأرز، ولذلك أُقيمت تجربتان حقليتان خلال

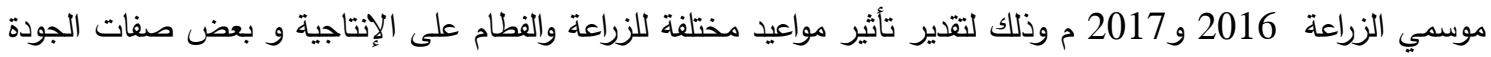
لصنف الأرز جيزة 179 وذلك فى المزرعة البحثية لمحطة البحوث الزراعية بسخا - كفر الثيخ - جمهورية مصر العربية.

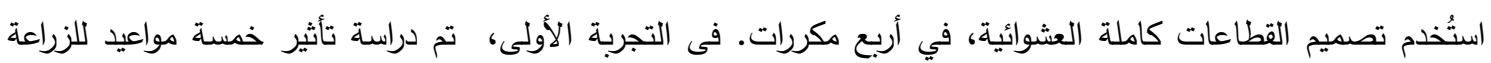

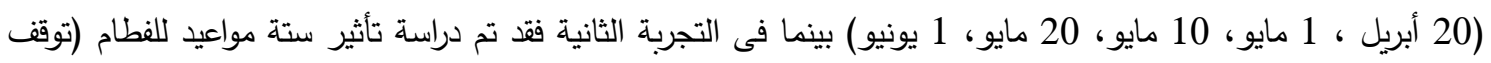

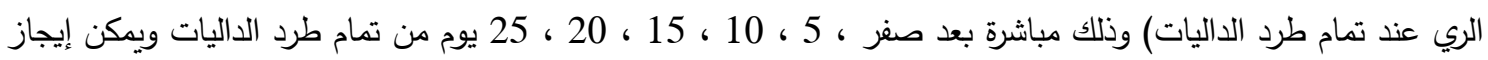
أهم النتائج فيما يلى : 1- وقد أوضحت نتائج التجربة الأولى أن ميعاد الزراعة المبكر فى 20 ابريل أدي إلى زيادة عدد الأيام حتى 50 \% تزهير ،

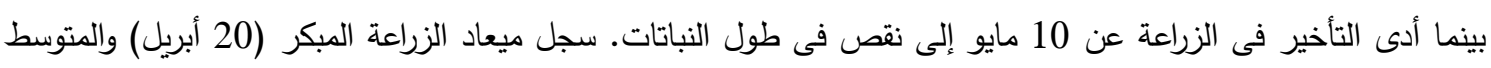

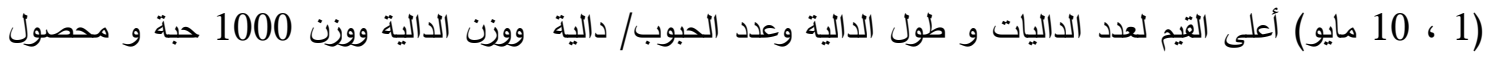

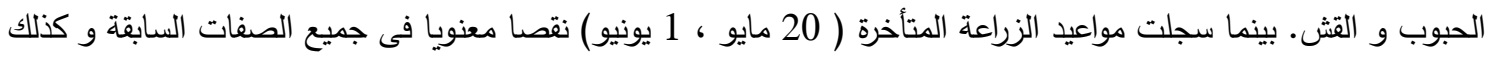

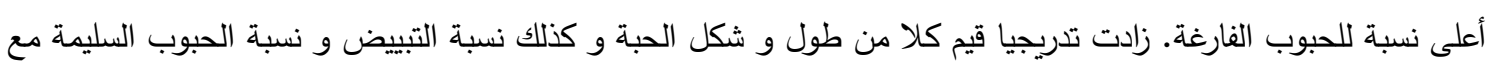
التأخير فى ميعاد الزراعة. و تشير النتائج أيضا إلى تأثر محتوى الأميلوز معنويا بمواعيد الزراعة المختلفة بينما لم يكن هناك

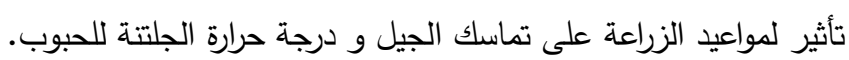

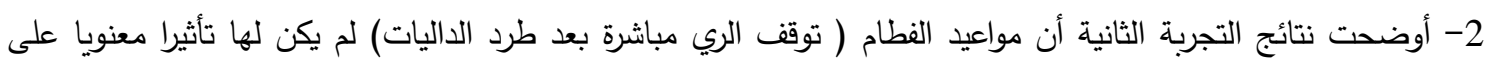

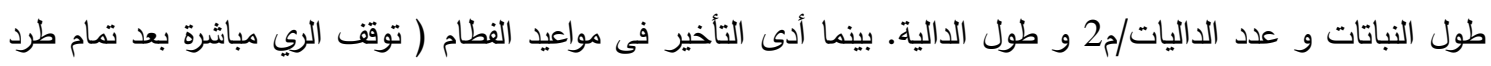

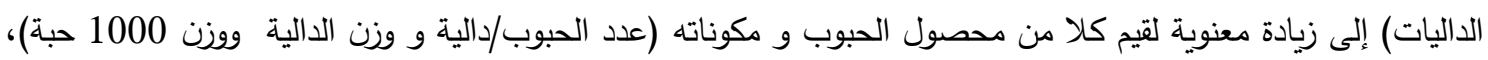

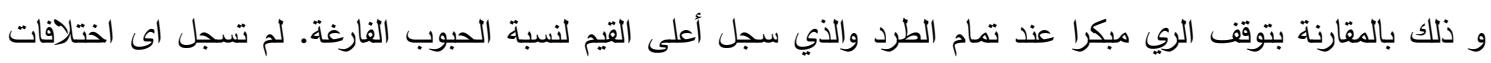

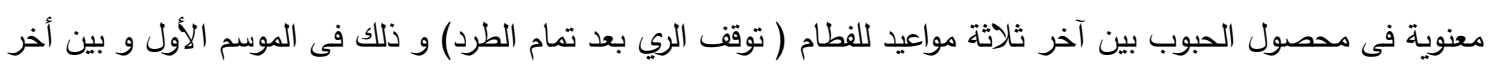

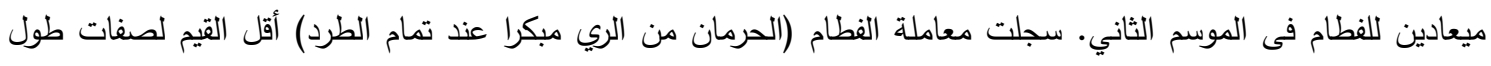

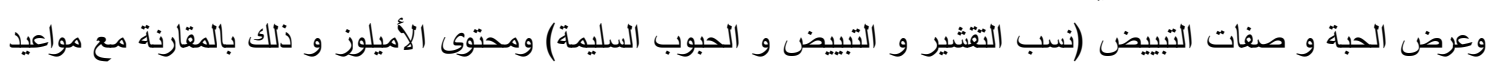

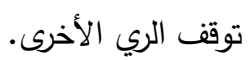

وأخيرا ، يمكن التوصية بأن مواعيد الزراعة فى 1 ، 10 مايو قد أدت إلى الحصول على أعلى القيم لمحصول الحبوب

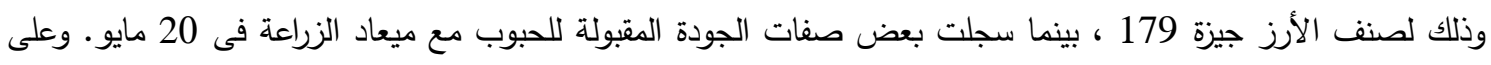

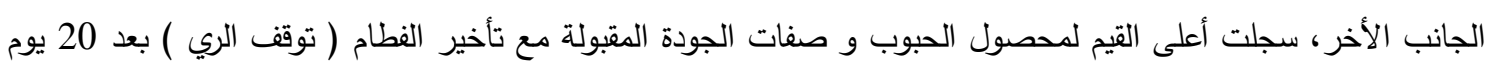
من تمام طرد الداليات.

كلية الزراعة - جامعة المنوفية مركز بحوث الأرز بسخا
أسماء السادة المحكمين

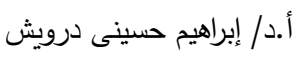

أ.د/ بسيونى عبدالرازق زايد إيرايم حسين دروبك 
